\title{
The fire resistant ceiling construction in a hydrocarbon fire
}

\author{
Marina Gravit $^{1}$, and Elena Golub ${ }^{1 *}$ \\ ${ }^{1}$ Peter the Great St. Petersburg Polytechnic University, St. Petersburg, Russian Federation
}

\begin{abstract}
Fire protection of building structures under the hydrocarbon fire is becoming more relevant, especially in the design and construction of oil and gas and chemical complex facilities, including offshore fixed platforms, liquefied natural gas production and storage facilities and other objects of the fuel and energy complex. The development dynamics of such a fire requires a different approach to testing the structures in order to determine the fire resistance limit. The fire resistance tests of a steel horizontal structure with a fire resistance suspended ceiling of PROMATECT-T plates were carried out under the condition of creating a hydrocarbon temperature combustion regime. A detailed description of the tested ceiling design is given. It is shown that at the time of the end of the fire action, the limit state due to the loss of load capacity (R) and loss of integrity (E) was not recorded when the test reached 120 minutes.
\end{abstract}

\section{Introduction}

Fires have a big impact on buildings and structures as directly when the fire is located on the site itself, and indirectly [1]. Therefore, the number of emergency actions [2] should include fire impacts arising from a fire, as well as the choice of space planning solutions [3] should be determined taking into account the requirements of fire safety. For example, the fire effect significantly changes the rigidity of steel beam-to-column connections [4], welded tubular joints are very defenseless without fire protection [5], and the aluminum parts of the structures are most exposed to melting during combustion [6]. In this way, the design of fire protection is a mandatory requirement in the design of structures $[7,8]$.

Protection of buildings and structures, equipment, structures of tankers and offshore platforms in the conditions of combustion of fire-hazardous and explosive substances at oil and gas facilities is an actual problem [9-12].

Until recently, in Russia, all tests of structures and materials were carried out only under conditions of a standard temperature regime, otherwise known as cellulose, whose combustion materials are wood, cloth, paper [13-17]. The test method is given in Russian State Standard GOST 302470-94 "Elements of building constructions. Fire-resistance test methods. General requirements", the method is identical to the international standard ISO 834-75" Fire resistance tests Elements of building constructions". Fires resulting from the burning of petroleum products, as a rule, can be attributed to the so-called hydrocarbon fire,

\footnotetext{
*Corresponding author: alen-go@bk.ru
} 
which is characterized by a rapid temperature rise, and is accompanied by a shock wave of flame on structures, fireproof coatings, combustible finishing and building materials $[18,19]$. Materials and structures that have proven effective under standard conditions, as a rule, can not provide the required level of protection under conditions of hydrocarbon fire [20].

The range of materials, burning of which refers to a hydrocarbon fire, is very wide. They can act not only pure hydrocarbons (gasolines and natural gases - methane, ethane, propane, butane, etc.), but also their organic derivative (alcohols, phenols, ketones), virtually all oil products, lubricants and varnishes, many plastics with a low oxygen index.

A detailed review of international standards for determining the fire resistance of structures under a hydrocarbon fire, as well as an analysis of technical regulations in the field of fire protection for ships and offshore platforms is given in [21]. The main documents on which such tests are conducted are the American standard UL 1709 «Standard for Safety for Rapid Rise Fire Tests of Protection Materials for Structural Steel» and European EN 13631: 2012 «Fire resistance tests. General requirements», EN 1363-2: 1999 «Fire resistance tests - Part 2: Alternative and additional procedures», ENV 1363-3 «Fire resistance tests - Part 3: verification of furnace performance».

Since June 1, 2015, the Russian State Standard GOST R EN 1363-2-2014 "Fire resistance tests. Alternative and additional procedures", in which the concept of "hydrocarbon curve" was introduced. This standard is identical to the European standard EN 1363-2: 1999.

At present, there is a tendency to simulate a hydrocarbon fire in different software complexes in order to determine the effect of fire on various structures [22-26].

One of the important approaches for ensuring fire safety of buildings and structures is the use of a method for analyzing, assessing and managing the risk of an accident. This method allows to develop the most safe and at the same time economical design solution [27-29].

The principle of passive fire protection in a hydrocarbon fire is to isolate the protected structure from fire. The insulation provides a thermal barrier, slowing the rate of heating of the steel and providing the required time for the fire extinguishing prior to the destruction of structures $[30,31]$.

One way to protect horizontal structural elements from the effects of a hydrocarbon fire is the fire resistant suspended ceilings, which relate to constructive fire protection. The use of constructive fire protection is considered to be the most effective method, from the number used today to protect the structures of buildings and structures from the effects of fire and high temperatures in fires. In addition, when using this type of fire protection there are no wet processes and work can be carried out at any ambient temperature.

Suspended ceilings are used to protect horizontal structures of coatings and slabs with steel beams and are structural and functional elements. Important advantages of such fire protection are the ease of the suspended ceiling, as well as the reliability of the structure due to the formation of an air gap, which additionally increases the fire resistance limit [32].

Also, fire resistant suspended ceilings serve to protect against fire engineering communications systems, such as ventilation and air conditioning systems, electricity supply. By installing this type of ceiling, an independent fire compartment is created for communications, protecting them in the inter-ceiling space and ensuring their fire safety.

In addition to protecting structures with steel beams, fire resistant suspended ceilings are also used to protect coatings from profiled sheets. In work [33], the influence of the gap size of the air layer on the fire resistance of the structure as a whole was investigated. Most of the studies are devoted to the development of either thin-layer fire retardant coatings [14-16], or constructive fire protection in the form of separate plate elements $[30,31]$, and holistic elements, such as a fire resistant suspended ceiling, are given little attention.

The ceiling design studied in this work is a PROMATECT-T plate $15 \mathrm{~mm}$ thick fixed to a steel substructure in two layers, with a heat-insulating layer of $200 \mathrm{~mm}$ rock wool slabs. 
PROMATECT-T plates are a product of Promat, the world's largest producer of flame retardant materials and high-temperature insulation. Thanks to their work, fire safety projects around the world have been implemented in civil and industrial construction, petrochemical, gas, nuclear and power engineering. In addition, the company is engaged in testing and certification of fire protection systems for steel, reinforced concrete, wooden structures and utilities. The assortment of fire resistant coatings Promat is presented by compositions of different type and purpose. This allows you to provide comprehensive protection for any object. The proposed fire retardant coatings are of high quality and at the same time costeffective.

The aim of the work was to select the thickness of the thermal insulation and the thickness of the fire resistant ceiling slabs to obtain the test results for the fire resistance parameters in the hydrocarbon fire for at least 150 minutes.

\section{Methods}

Tests of prototypes of the construction of a fire resistant suspended ceiling were carried out to determine the flame retardant efficiency of the samples presented in accordance with Russian State Standards GOST 30247.0-94 "Elements of building constructions. Fireresistance test methods. General requirements" and GOST R 53298-2009 "Suspended ceilings. Fire resistance test method".

For the tests, 2 samples of the design of the fire resistant suspended ceiling with dimensions of $5000 \times 3000 \times 545 \mathrm{~mm}$ were presented, the height is indicated taking into account the metal prefabricated substructure made of the rolling profiles of the angular and I-section sections.

The metal frame of the suspended ceiling was made by installing vertical supports welded to the beams of the I-section profile No. 20B1 in accordance with Russian State Standard GOST 26020-83 (reduced thickness of metal - $3.4 \mathrm{~mm}$ ), set in the number of 5 pieces. To these supports longitudinal guides were welded from the double angle 40x4 $\mathrm{mm}$ in accordance with Russian State Standard GOST 8509-93, and in the transverse direction the guides were connected by double angles $40 \times 4 \mathrm{~mm}$ welded to the side by side elements. Thus, the nominal pitch of the metal elements of the framework of the fire resistant suspended ceiling, forming a flat welded cage for fixing the plate materials of the enclosing part, was $626-1250 \mathrm{~mm}$.

At the bottom of the flat welded cage of the metal frame of the suspended ceiling, strips of width $160 \mathrm{~mm}$, made of PROMATECT-T plates $15 \mathrm{~mm}$ thick, fastened to the metal substructure with self-tapping screws, were fastened. After that, over the metal elements of the frame, a two-layer covering was made with PROMATECT-T plates $15 \mathrm{~mm}$ thick $(2 \times 15=30$ $\mathrm{mm})$, fasteners of which were made with self-tapping screws and staples installed with a pitch $(300 \pm 10) \mathrm{mm}$.

At the end of the assembly of the enclosing part of the suspended ceiling from PROMATECT-T slabs, a metal grid with a cell of 100x100 mm made of a wire of $05 \mathrm{~mm}$ and 4 layers of heat insulation boards made of rock wool $50 \mathrm{~mm}$ thick and with a density of $60 \mathrm{~kg} / \mathrm{m} 3$ was laid along the top of the steel angles. The total thickness of the thermal insulation layer was $200 \mathrm{~mm}$.

In order to simulate the construction of the ceiling and ensure the thermal regime of heating the metal structures of the suspended ceiling protected by the enclosure, the steel Ibeam beams were laid with reinforced concrete covering plates. On the perimeter, the sides of the prototype were covered with slabs of incombustible mineral wool insulation. To simulate the mode of movement of air in the allocated space above the fence of the fire resistant suspended ceiling, along the end parts of the samples, a device of openings $300 \times 500$ $\mathrm{mm}$ in size was provided. 
The ambient temperature and the relative humidity of the air during the first test were 21 ${ }^{\circ} \mathrm{C}$ and $50 \%$, respectively, in the second, these readings were equal to $23{ }^{\circ} \mathrm{C}$ and $52 \%$. The speed of air movement in both tests did not exceed $0.5 \mathrm{~m} / \mathrm{sec}$.

\subsection{Test procedure}

The experimental samples were placed on an experimental setup and subjected to unilateral thermal action.

In the fire chamber of the furnace, a hydrocarbon temperature regime was created in accordance with Russian State Standard GOST R EN 1363-2-2014, characterized by the following relationship:

$$
T=1080\left(1-0.325 \mathrm{e}^{-0.167 t}-0.675 \mathrm{e}^{-2.5 t}\right)+20
$$

where $T$ - the temperature in the furnace, corresponding to the time $\mathrm{t},{ }^{\circ} \mathrm{C}$;

$t$ - time, calculated from the beginning of the test, min.

The temperature in the fire chamber of the furnace was measured by furnace thermocouples, evenly distributed along the length of the sample at six locations.

On the experimental samples, the temperature was measured by thermocouples installed in an amount of 9 pieces on the I-beams of the metal skeleton of the suspended ceiling in the middle of their spans (with the exception of the two outer beams), in accordance with the requirements set out in 5.4.4 Russian State Standard GOST R 53295-2009.

\section{Results and Discussion}

Curves of temperature changes in the controlled points on the I-beam steel beams of the prototype of the fire resistant suspended ceiling are shown in Fig. 1 and Fig. 2.

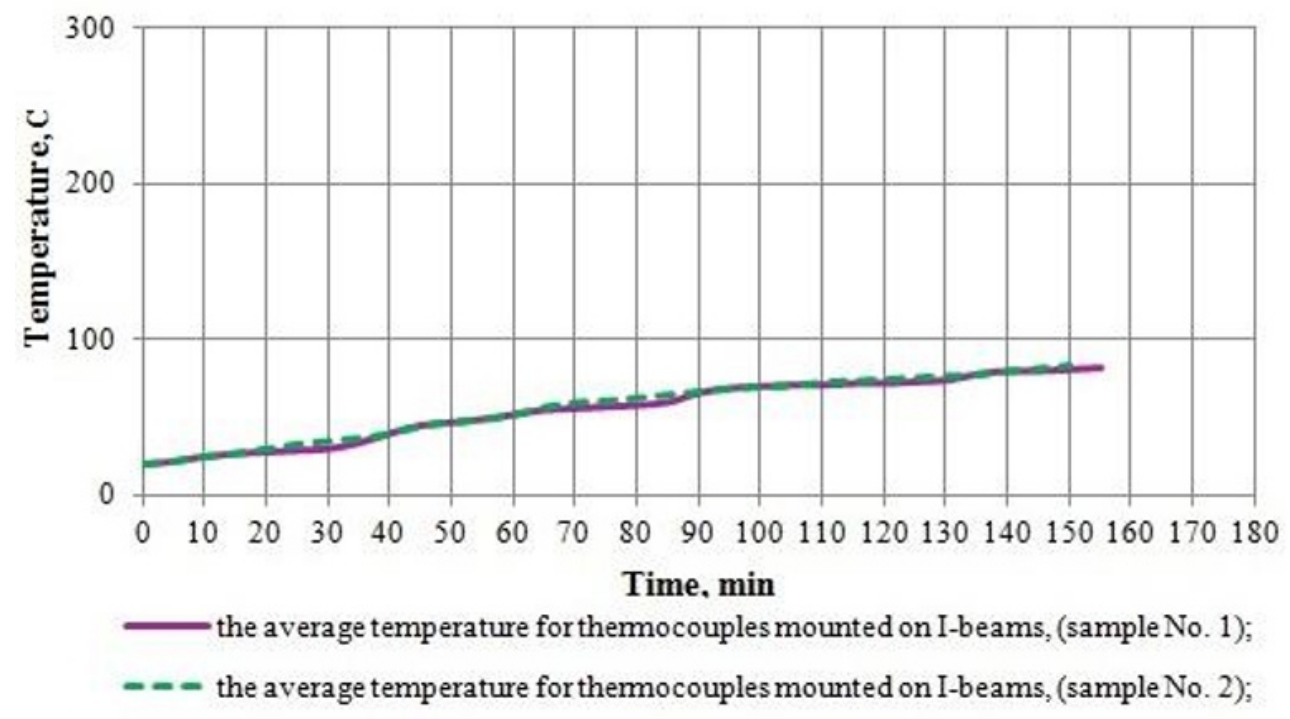

Fig. 1. Curves of temperature changes on I-beams of steel frameworks. 


\section{EECE-2018}

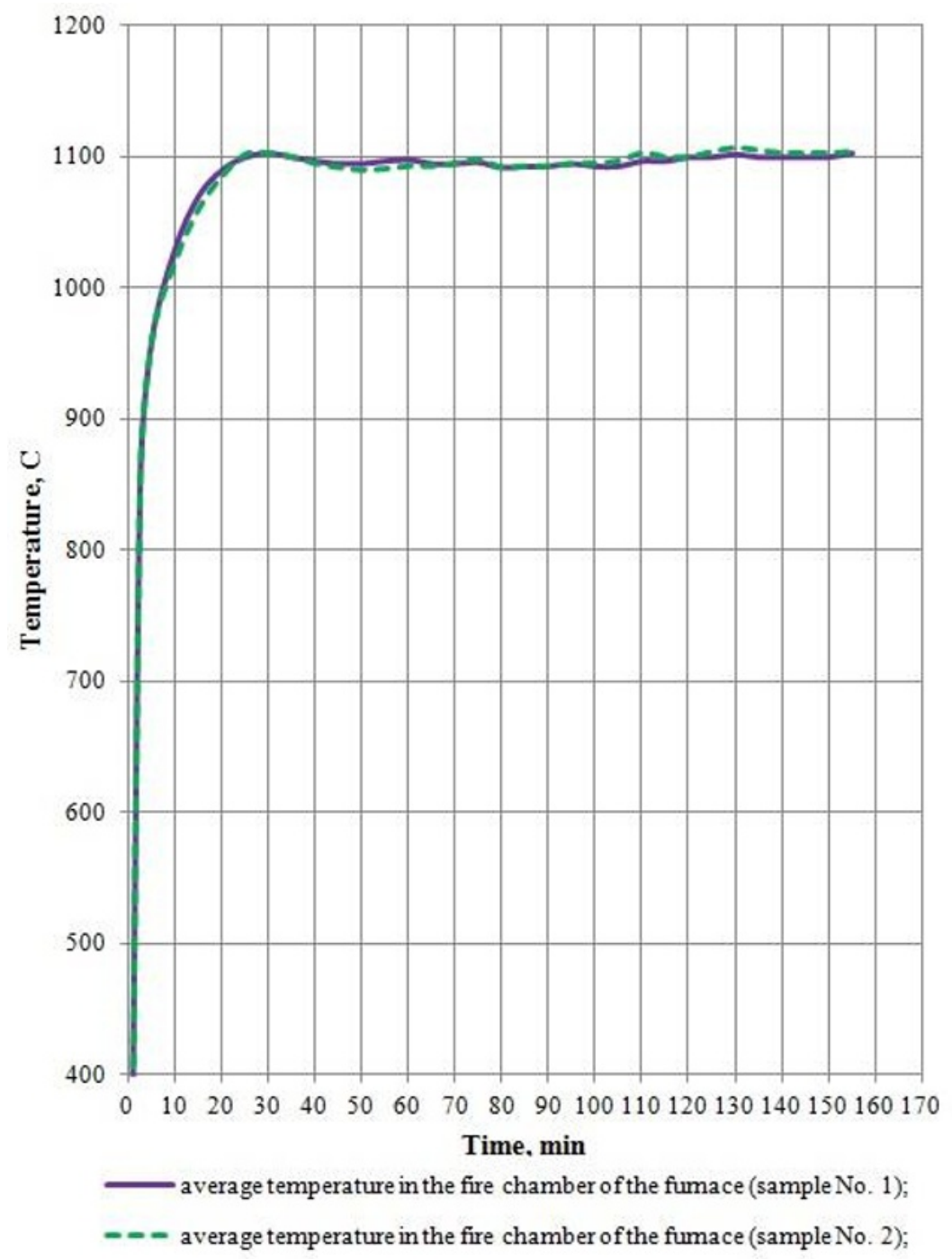

Fig. 2. Curves of temperature changes in the fire chamber of the furnace.

Upon agreement with the customer, the tests were terminated at the 155 th minute. During the testing of the prototypes of the fire resistant suspended ceiling, no visible changes were observed in the state of the protecting parts of the PROMATECT-T plates.

At the time of the end of the fire impact (155 min), the wall part of the PROMATECT-T plates did not collapse. Displacements and violations of the integrity of the layer of insulation from rock wool is not fixed. The deformation of the steel elements of the skeleton of the suspended ceiling has not been observed.

At the time of the end of the fire action, the average temperature for the thermocouples installed on the steel I-beams of the frame was 75 and $82^{\circ} \mathrm{C}$ for the 1 st and 2 nd samples, respectively.

Thus, none of the limiting states for which the tests were conducted was achieved during the time of fire tests.

Partial collapse of the plates of the fencing part of the suspended ceiling was recorded after the cooling of the prototypes. 

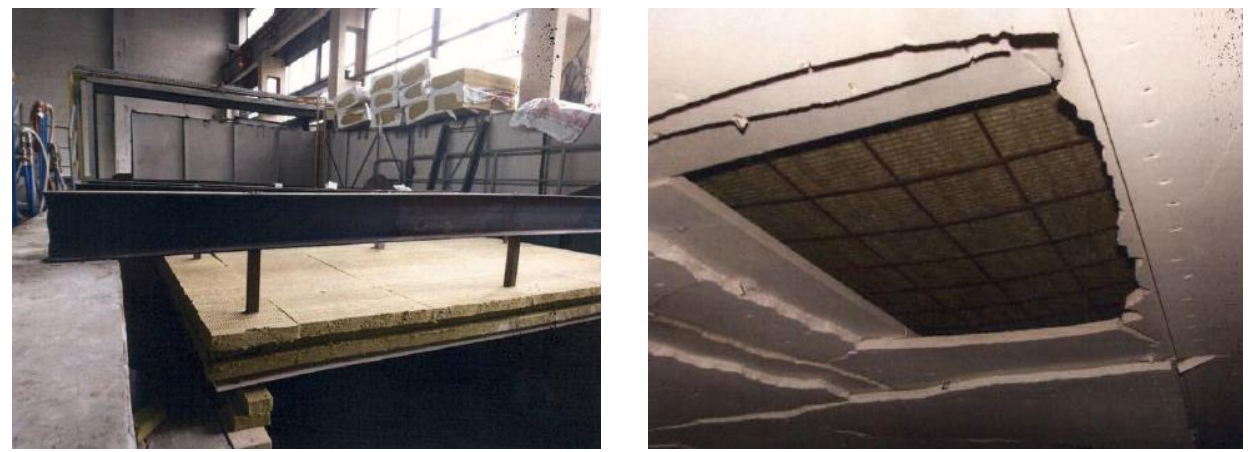

Fig. 3. A sample of the ceiling design before the test (left) and partial collapse of the enclosing part of the suspended ceiling during cooling (right).

The fire resistant suspended ceiling showed its effectiveness not only under standard conditions [32,33], but also under conditions of hydrocarbon fire. Therefore, testing this design under different conditions is necessary to create a complete picture of the behavior of the suspended ceiling, which will allow more extensive use this type of passive fire protection for horizontal structures of ceilings and slabs. Most of the studies are devoted to the development of either thin-layer fire retardant coatings [14-16], or constructive fire protection in the form of separate plate elements [30,31], and holistic elements, such as a fire resistant suspended ceiling, are given little attention.

\section{Conclusions}

The prototype of a fire resistant suspended ceiling design made of PROMATECT-T slabs 30 $\mathrm{mm}$ thick fixed to a steel sub-structure in two layers with a heat-insulating layer made of rock wool slabs was tested provided that a hydrocarbon temperature regime was created in the fire chamber of the furnace in accordance with GOST R EN 1363 -2-2014, according to the results of which it is established:

- $\quad$ at the time of the end of the fire impact $(155 \mathrm{~min})$, the loss of load-bearing capacity of the suspended ceiling design or the occurrence of ultimate deformations is not fixed;

- the critical temperature of $500^{\circ} \mathrm{C}$ during the test period $(155 \mathrm{~min})$ was not reached on the steel I-beams of the prototypes (the average temperature for the thermocouples installed on the steel I-beams of the frame, at the time of the end of the fire impact, was 75 and $82^{\circ} \mathrm{C}$, for 1 st and 2 nd sample, respectively).

The ceiling design using PROMATECT-T boards proved its effectiveness in the hydrocarbon temperature regime.

\section{References}

1. K.O. Fryanova, V.A. Perminov, Mag. Civ. Eng., 7, 15-22 (2017)

2. A.V. Alekseytsev, N.S. Kurchenko, Mag. Civ. Eng., 73 (5), 3-13 (2017)

3. N.V. Gusakova, K.E. Filyushina, A.M. Gusakov, N.N. Minaev, Mag. Civ. Eng., 75 (7), 84-93 (2017)

4. V.M. Tusnina, Mag. Civ. Eng., 73 (5), 25-39 (2017)

5. M.R. Garifullin, A.V. Barabash, E.A. Naumova, O.V. Zhuvak, T. Jokinen, M. Heinisuo, Mag. Civ. Eng., 63 (3), 53-76 (2016) 
6. A. Hirkovskis, D. Serdjuks, V. Goremikins, L. Pakrastins, N.I. Vatin, Mag. Civ. Eng., 57 (5), 86-96 (2015)

7. T. Saknite, D. Serdjuks, V. Goremikins, L. Pakrastins, N.I. Vatin, Mag. Civ. Eng., 4, 26-39 (2016)

8. I.N. Priadko, V.P. Mushchanov, H. Bartolo, N.I. Vatin, I.N. Rudnieva, Mag. Civ. Eng., 65 (5), 27-41 (2016)

9. M. Imran, M.S. Liew, M.S. Nasif, Chem. Engineer. Trans., 45, 1951-1956 (2015)

10. J. Czuiko, J.K. Paik, Mar. Technol., 49, 23-25 (2012)

11. M. Imran, M.S. Liew, M.S. Nasif, U.M. Niazi, A. Yasreen, Adv. Sci. Lett., 23, 12431247 (2017)

12. M.V. Gravit, E.V. Golub, S.P. Antonov, Mag. Civ. Eng., 79 (3), 86-94 (2018)

13. M.V. Gravit, E.S. Nedviga, N.A. Vinogradova, J.S. Teplova, Construction of Unique Buildings and Structures, 51 (12), 73-83 (2016)

14. P. Schaumann, F. Tabeling, W. Weisheim, Stahlbau, 83 (9), 646-651 (2014)

15. P. Schaumann, T. Kirsch, J. Struct. Fire Eng., 6 (1), 41-48 (2015)

16. P. Kraus, M. Mensinger, F. Tabeling, P. Schaumann, J. Struct. Fire Eng., 6 (4), 237-246 (2015)

17. M.K. Bronzova, M.R. Garifullin, Construction of Unique Buildings and Structures, 42 (3), 61-78 (2016)

18. A. Shvyrkov, I. Yuryev, Technologies of Technospheric Safety, 68 (4), $50-56$ (2016)

19. V.I. Golovanov, A.V Pekhotikov, V.V Pavlov, Oil and Gas Territory, 4, 72-77 (2007)

20. I.R. Khasanov, M.V. Gravit, A.A. Kosachev, A.V. Pekhotikov, B.V. Pavlov, Fire and Explosion Safety, 23 (3), 49-57 (2014)

21. M. Gravit, E. Gumerova, A. Bardin, V. Lukinov, International Scientific Conference Energy Management of Municipal Transportation Facilities and Transport EMMFT 2017 (Springer, Cham, 2018)

22. E. Palazzi, B. Fabiano, Process Saf. Environ., 90, 121-128 (2012)

23. A.Yu. Shebeko, Yu.N. Shebeko, D.M. Gordienko, Fire Safety, 1, 25-29 (2017)

24. A.Yu. Shebeko, Yu.N. Shebeko, Fire Safety, 2, 46-49 (2017)

25. I. Payá-Zaforteza, M.E.M. Garlock, Structures in Fire - Proceedings of the Sixth International Conference (DEStech Publications, Inc., Lancaster, 2010)

26. F.M. Gimranov, Vestnik Kazanskogo Tekhnologicheskogo Universiteta, 5, 158-161 (2010)

27. J.K. Paik, J. Czujko, Trans. - Soc. Nav. Archit. Mar. Eng., 120, 167-197 (2013)

28. A.V. Mordvinova, D.M. Gordiyenko, Yu.N. Shebeko, A.Yu. Lagozin, V.P. Nekrasov, Gas Industry, 716, 30-34 (2014)

29. J.K. Paik, J. Czujko, IES J. Part A Civ. Struct. Eng., 4, 167-179 (2016)

30. D.A. Dybal, O.N. Shishilov, I.V. Garustovich, Paintwork Materials and their Application, 6, 16-19 (2017)

31. S. Shabalin, Gas Industry, 9, 122-125 (2017)

32. V.I. Golovanov, E.V. Kuznetsova, Industrial and Civil Construction, 9, 82-90 (2015)

33. A.F. Zharkov, F.A. Zharkov, O.G. Chesnokova, Internet-Vestnik VolgGASU, 40 (4), 10 (2015) 